\title{
Implementation of Discovery Learning to Improve Scientific and Cognitive Attitude of Students
}

\author{
Erman Syarif $^{1}$, Syamsunardi ${ }^{2}$, Alief Saputro ${ }^{3}$ \\ ${ }^{1}$ Geography, Universitas Negeri Makassar, Indonesia \\ Email: ermansyarif@unm.ac.id, \\ ${ }^{2}$ Geography, Universitas Negeri Makassar, Indonesia \\ Email: syamsunardi.as.syam@gmail.com, \\ ${ }^{3}$ Geography, Universitas Negeri Makassar, Indonesia \\ aliefsaputro23@gmail.com
}

(Received: January-2020; Reviewed: January-2020; Accepted: March-2020; Available online: March 2020; Published: April-2020)

\begin{abstract}
This study aims to determine the implementation of discovery learning in improving scientific and cognitive attitudes of students. This type of research is a classroom action research conducted in class X Is7. Each cycle consists of four stages, namely planning, implementing, observing, and reflecting. The instruments in this study were observation sheets, scientific attitude questionnaires and cognitive tests. The results showed: 1) the scientific attitude of the first cycle students showed an average value of 3.9 in either category. Cycle II scientific attitudes of students showed an average value of 4.4 in either category. 2) the average cognitive value in the first cycle with a value of 70.18 in the sufficient category and an increase in the second cycle with a value of 89.23 in the very high category. This improvement illustrates that students have an effort in mastering subject matter. Discovery learning has a positive impact in improving students 'scientific and cognitive attitudes which are marked by an increase in students' learning completeness in each cycle.
\end{abstract}

Keywords: discovery learning, geography learning, scientific attitude, cognitive, students

\section{INTRODUCTION}

The learning process will take place maximally if the teacher masters the subject matter, learning models and can use appropriate learning media that are expected to be able to help students achieve maximum learning outcomes. (Sulfemi, 2016) revealed that through methods and learning media teachers can more effectively achieve the achievement of learning objectives. One of the geographic material which involves a lot of concepts is natural disaster mitigation and adaptation material. The many concepts on natural disaster mitigation and adaptation material make students have difficulty in learning and understanding the material if students are taught with a model that is not in accordance with the characteristics of the material. this can affect the low geography learning outcomes. Therefore, it is necessary to use a learning model in accordance with the characteristics of the material, especially those that can help students in constructing all concepts well.

The 2013 curriculum is aimed at developing and building the potential character of students, where teachers must be innovative in developing learning models, one of which is discovery learning (Kauchak \& Eggen, 1992) ideal learning is learning that is oriented towards students, where students will try to construct their own knowledge and are actively involved in finding information. Teacher guidance and active involvement in the learning process is a key element in achieving optimal learning outcomes 
(Hunter \& Elliott-Kingston, 2014). The application of discovery learning models in the learning process as an alternative problem solving and improvement of scientific thinking skills for students (Prakasiwi \& Ismanto, 2018). There is a significant effect of the application of learning models on student learning outcomes (Suendartia, 2017). Professional teachers are determinants of a quality education process (Darling-Hammond, 2017).

The discovery learning model is one of the learning models that emphasize understanding of learning material. Based on facts and observations, the application of learning discovery has advantages that can help students in improving and improving cognitive skills and processes (Castronova, 2002). There are differences in understanding of scientific concepts and attitudes between students in the discovery learning model and the direct learning model (Widiadnyana et al., 2014). Discovery learning will increase activities and make students more enthusiastic in learning which will have an impact on improving student learning outcomes (Wahjudi, 2015). The application of discovery learning models to natural science learning was proven to be helpful in improving the results of students' scientific literacy (YAUMI, 2017). Through this learning process, discovery is expected to have a good influence on the effectiveness and learning outcomes of students. Discovery learning involves students actively investigating problems and will have an impact on the achievement of learning outcomes (Putriani \& Rahayu, 2018).

Based on preliminary studies in odd semester 2018/2019 class X Is7 SMA Negeri 2 Takalar namely: 1) the low average value of learning outcomes reached 68.34 in geography subjects, 2) $63.33 \%$ of students in class X Is7 experienced incompleteness in geography subjects, classically the percentage of students' mastery learning in geography is still below $75 \%$, 3) $56.67 \%$ of students lack concentration, lack of independence, and do not pay attention to the teacher's explanation, 4) $60 \%$ of students assume learning in class is very dependent on the direction and control of the teacher, the teacher becomes the main source of learning in the learning process, and 5) $70 \%$ of students have difficulty in understanding the concepts, especially natural disaster mitigation, and adaptation materials.

Based on the facts and results of the preliminary study it is necessary to apply a learning model that is in line with the 2013 curriculum so that the scientific and cognitive attitudes of students in geography learning can be improved. The application of an appropriate learning model and in accordance with the characteristics of students and the conditions of the material taught is very influential on the achievement of learning objectives. Through the learning process, discovery learning is expected to have a good influence on the effectiveness and learning outcomes of students in geography subjects.

The purpose of this study was to determine the implementation of discovery learning in improving the scientific and cognitive attitudes of students in learning geography. The hypothesis in this study is the implementation of discovery learning in geography learning in accordance with the syntax that is believed to improve the scientific and cognitive attitudes of students.

\section{METHOD}

This study was designed using a class action research in class X Is7 of SMA Negeri 2 Takalar with 30 students consisting of 13 males and 17 females. Each cycle consists of four stages, namely planning, action, observation, and reflection. The four stages in classroom action research are shown in Figure 1.

The instruments used in this study were observation sheets, scientific attitude questionnaires, and students' cognitive tests. The data obtained are the activities of teachers and students, the scientific and cognitive attitudes of students in each cycle. The scientific attitude questionnaire was made using a Likert scale. The questionnaire is given to students who have participated in learning activities with discovery learning models at the end of learning activities. 


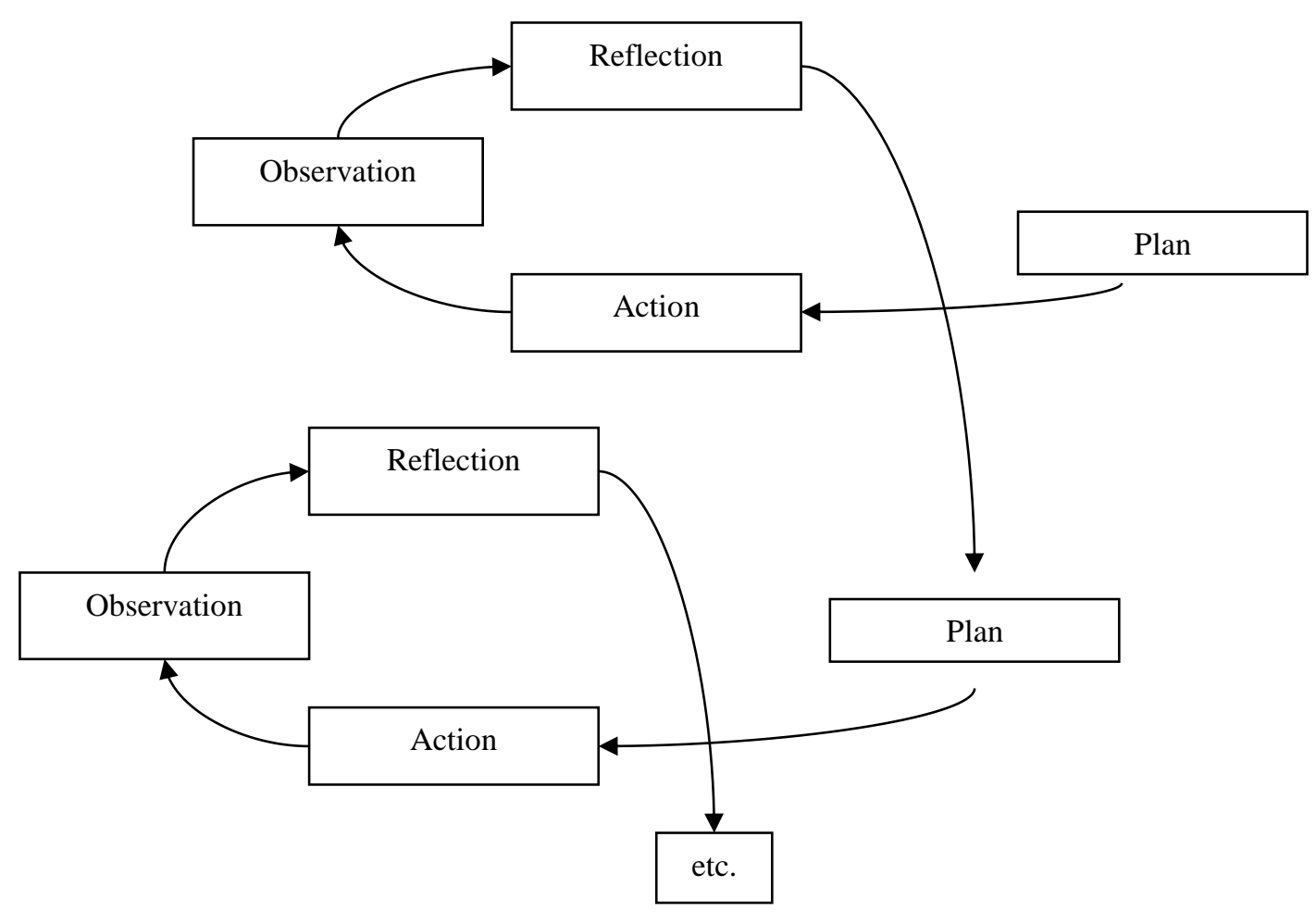

Figure 1. Flowchart of Implementation in Classroom Action Research (Kemmis et al., 2013)

Table 1. Activity Criteria Interval

\begin{tabular}{ll}
\hline Persentage $(\%)$ & Rating Category \\
\hline$>80$ & Very Good \\
$75-79,9$ & Good \\
$70-74,9$ & Enough \\
$60-69,9$ & Less \\
$0-59,9$ & Very Less \\
\hline
\end{tabular}

source : (Arikunto, 2010)

Table 2. Student Mastery Learning Interval Criteria

\begin{tabular}{ll}
\hline Persentase $(\%)$ & Rating Category \\
\hline$>80 \%$ & Very High \\
$75 \%-79,9 \%$ & High \\
$70 \%-74,9 \%$ & Enough \\
$60 \%-69,9 \%$ & Low \\
$0 \%-59,9 \%$ & Very Low \\
\hline
\end{tabular}

source : (Arikunto, 2010)

Table 3. Interval Category Questionnaire Assessment of Scientific Attitudes of Students

\begin{tabular}{lll}
\hline No & $\begin{array}{l}\text { Category Questionnaire Scores for Scientific Attitudes of } \\
\text { Students }\end{array}$ & Interval \\
\hline 1 & Very Good & $4,2<\mathrm{x} \leq 5$ \\
2 & Good & $3,4<\mathrm{x} \leq 4,2$ \\
3 & Enough & $2,6<\mathrm{x} \leq 3,4$ \\
4 & Less & $1,8<\mathrm{x} \leq 2,6$ \\
5 & Very Less & $1,0<\mathrm{x} \leq 1,8$ \\
\hline
\end{tabular}

Source : (Arikunto, 2010) 
Data analysis of the results of learning achievement through the application of discovery learning models

Achievement Score $=\frac{\sum \text { Score Obtained }}{\sum \text { Score maximal }} \times 100 \%$ (Indarti, 2008)

To calculate the percentage of mastery learning by applying the Discovery Learning model the following formula is used:

\section{RESULT AND DISCUSSION}

\section{Result}

Discovery learning is a series of learning activities that maximally involve all the abilities of
Percentage of completeness of students $=$ $\frac{\sum \text { Score Obtained }}{\sum \text { Score maximal }} \times 100 \%$ (Sanjaya, 2010)

To calculate the percentage of improvement by applying the Discovery Learning model the following formula is used:

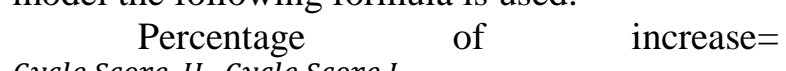
$\frac{\text { Cycle Score II-Cycle Score I }}{\text { Cycle Score I }} \times 100 \%$

(Daryato, 2011)

students in finding, investigating systematically, critically, logically, analytically so that they can formulate their own findings which include aspects of knowledge, skills, and attitudes. The syntax of discovery learning in natural disaster mitigation and adaptation material is as in table 4 .

Table 4. The syntax of discovery learning in natural disaster mitigation and adaptation material.

\begin{tabular}{|c|c|c|c|}
\hline \multirow[t]{2}{*}{ No } & \multirow{2}{*}{$\begin{array}{l}\text { The syntax of discovery } \\
\text { learning }\end{array}$} & \multicolumn{2}{|c|}{ Learning Activity Description } \\
\hline & & Teacher's Activity & Student Activity \\
\hline 1 & Stimulation & $\begin{array}{l}\text { Focusing the attention } \\
\text { of students }\end{array}$ & $\begin{array}{l}\text { - Learners know the types and } \\
\text { characteristics of natural disasters } \\
\text { - Students observe the distribution of areas } \\
\text { prone to natural disasters in Indonesia } \\
\text { and are asked to read textbooks and other } \\
\text { sources that contain reviews, images, } \\
\text { illustrations, and animations about the } \\
\text { types and characteristics of natural } \\
\text { disasters, the distribution of areas prone } \\
\text { to natural disasters in Indonesia, efforts } \\
\text { to reduce the risk of natural disasters }\end{array}$ \\
\hline 2 & $\begin{array}{l}\text { Identification } \\
\text { problems }\end{array}$ & $\begin{array}{lr}\text { Instruct } & \text { students to } \\
\text { identify } & \text { problems } \\
\text { through } & \text { exploratory } \\
\text { questions } & \end{array}$ & $\begin{array}{l}\text { - Students do data collection about news } \\
\text { that is published in newspapers or } \\
\text { magazines and then displayed in class so } \\
\text { students can exchange information about } \\
\text { the need for mitigation and adaptation to } \\
\text { natural disasters. }\end{array}$ \\
\hline 3 & Data collection & $\begin{array}{l}\text { Directing students to } \\
\text { make observations }\end{array}$ & $\begin{array}{l}\text { students are assigned to search for } \\
\text { information or materials to answer and } \\
\text { prove the proposed hypothesis related to } \\
\text { natural disaster mitigation materials. } \\
\text { students are assigned to discuss in groups } \\
\text { about mitigation and adaptation } \\
\text { measures for natural disasters } \\
\text { (earthquakes, volcanoes erupt, floods, or } \\
\text { other forms of disaster) if they occur in } \\
\text { their area. } \\
\text { students are assigned to sketch } \\
\text { evacuation routes when natural disasters } \\
\text { occur in their area. }\end{array}$ \\
\hline 4 & Data processing & $\begin{array}{l}\text { Directing students to } \\
\text { process observational } \\
\text { data. }\end{array}$ & - $\quad$ Students report systematic observations. \\
\hline
\end{tabular}




\begin{tabular}{llll}
\hline 5 Proof & $\begin{array}{l}\text { Extract information } \\
\text { about natural disaster } \\
\text { mitigation }\end{array}$ & $\begin{array}{l}\text { Students answer questions about } \\
\text { questions related to natural disaster } \\
\text { mitigation. } \\
\text { students are asked to give examples of } \\
\text { cases to clarify the concept of disaster } \\
\text { mitigation and adaptation that they have }\end{array}$ \\
& & $\begin{array}{l}\text { learned with real symptoms and } \\
\text { phenomen in the surrounding } \\
\text { environment so that the material becomes } \\
\text { meaningful. }\end{array}$ \\
\hline 6 & Draw a conclusion & $\begin{array}{l}\text { Guiding students to students conclude the learning outcomes } \\
\text { conclude learning } \\
\text { outcomes }\end{array}$ &
\end{tabular}

Syntax Learning discovery learning on natural disaster mitigation and adaptation material, wherein the process of learning activities carried out by teachers and students interact in the learning process. Syntax Learning discovery learning from stimulation to the conclusion.

\section{Teacher Activity}

Data about teacher activities in the learning process through the application of discovery learning models, from the two cycles that have been implemented there, is an increase in teacher activity as shown in Figure 2:

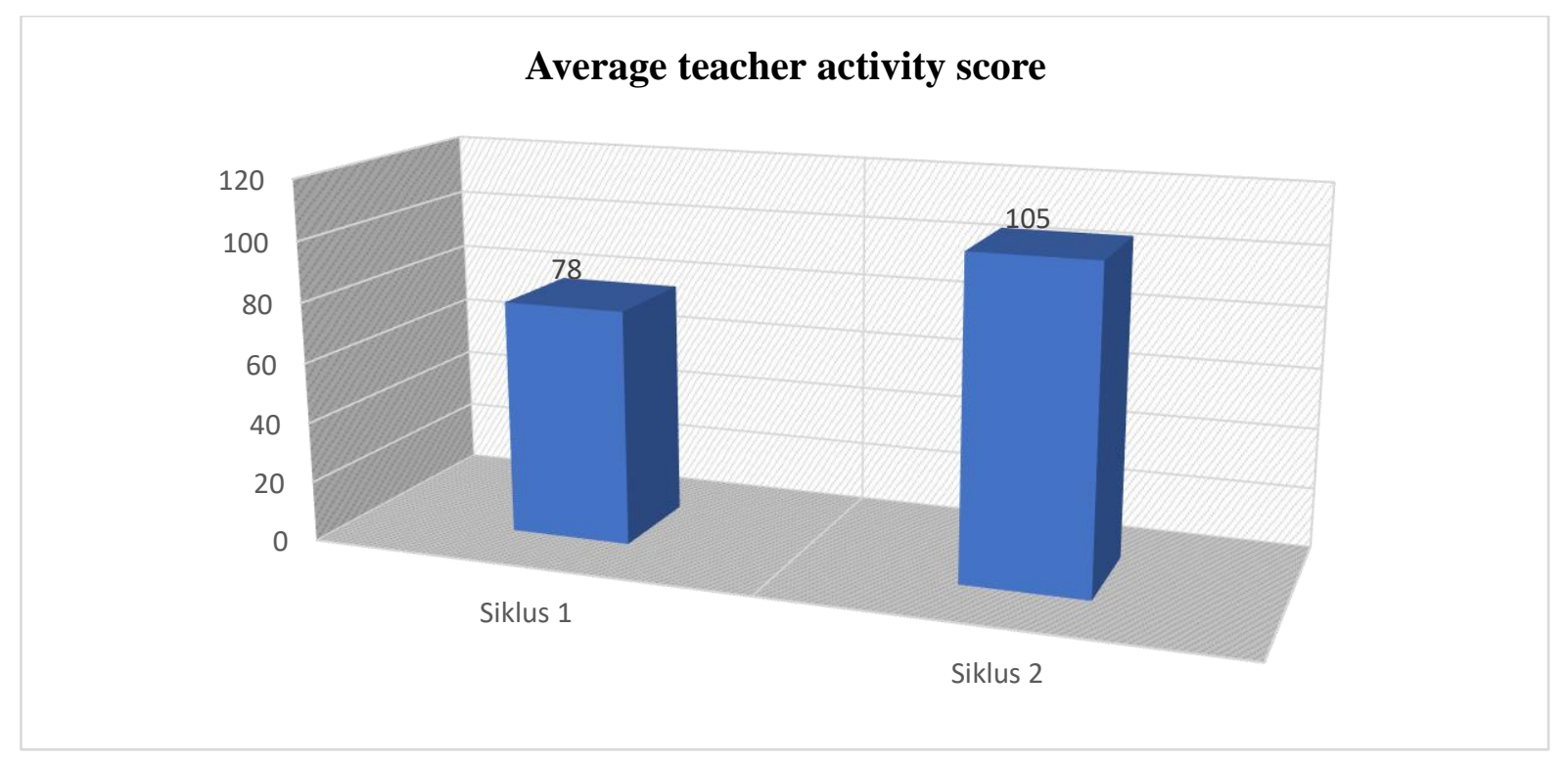

Figure 2. Teacher activity scores for a cycle

The average score of teacher activity obtained in the first cycle is 78 with a good category, an increase in the second cycle obtained an average score of 105 with a very good category. This increase occurred because of the reflection or improvement of teacher activities in learning activities in each cycle.

\section{Student Activities}

Based on the research results of student activity data in the learning process through the application of discovery learning models, of the two cycles that have been implemented there is an increase in teacher activity as shown in Figure 3: 


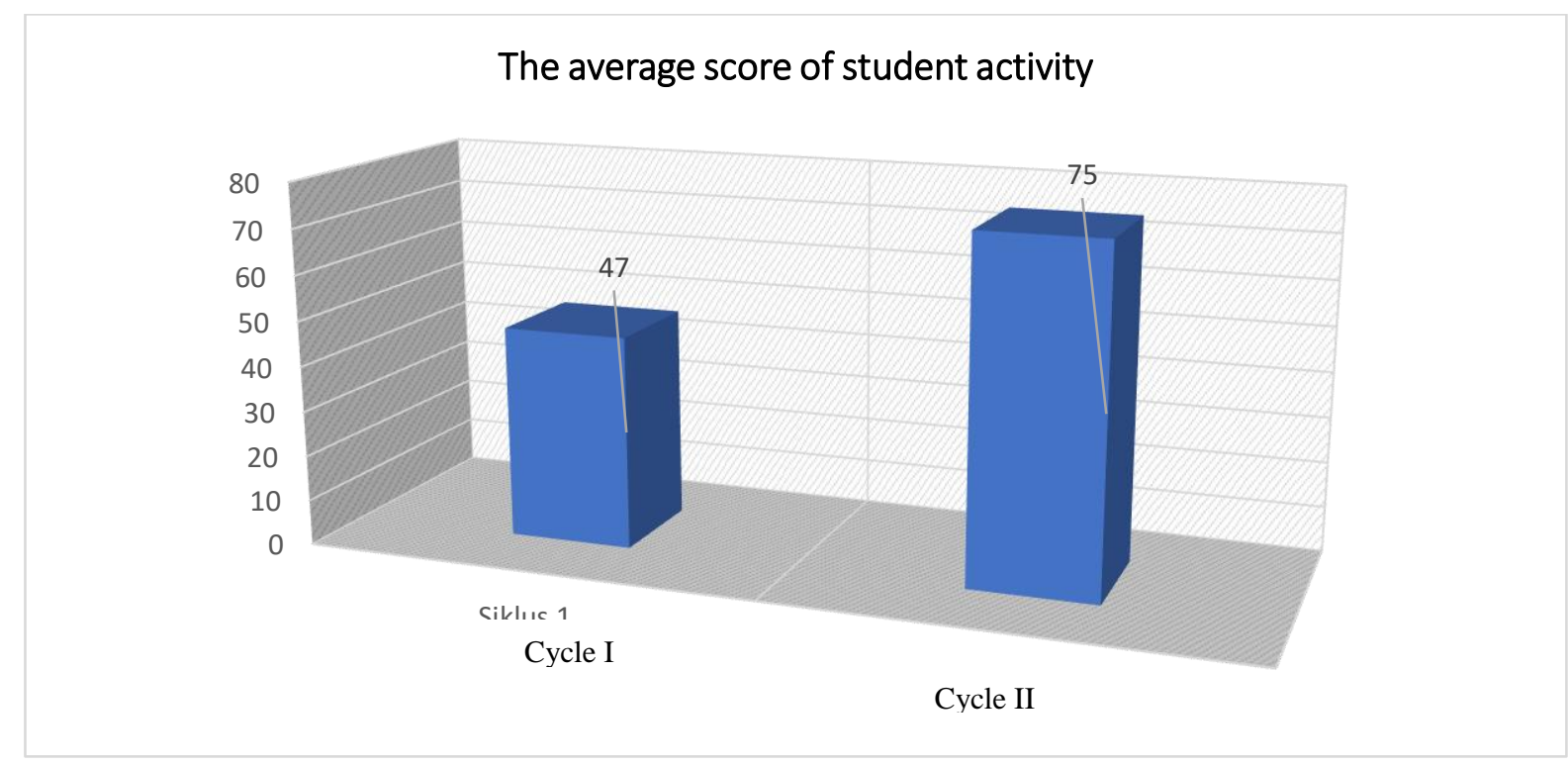

Figure 3. Activity scores of cycle students

The average score of students' activity scores obtained in the first cycle is 47 with a very low category, increasing in the second cycle obtained an average score of 75 with a good category. Improvement of students' learning activities in the learning process through the application of the discovery learning model each cycle is carried out improvement over the deficiencies/weaknesses that appear in each cycle and re-planned so that the learning process in the next cycle becomes better.

\section{Scientific Attitudes of Students}

The results of the scientific attitude assessment scores in the learning process through the application of the discovery learning model, of the two cycles that have been implemented there, is an increase in mastery learning as in table 5

Tabel 5. Scientific attitudes of students

\begin{tabular}{lll}
\hline \multirow{2}{*}{ Scientific attitude } & \multicolumn{2}{c}{ Average Score } \\
\cline { 2 - 3 } & Cycle 1 & Cycle II \\
\hline Want to know & 3,6 & 4,2 \\
Found something new & 4,1 & 4,3 \\
Open minded & 4,2 & 4,4 \\
Perseverance & 3,8 & 4,5 \\
Average & 3,9 & 4,4 \\
\hline Information & Good & Very Good \\
\hline
\end{tabular}

The acquisition of scientific attitudes assessment scores of students has increased. In the first cycle, the average scientific attitude of students was 3,9 in the good category and in the second cycle, the average scientific attitude of the students reached 4,4 in the very good category. This increase occurs because each meeting has a reflection so that the next learning will be better and optimal.

\section{Cognitive Learners}

Based on students' cognitive data in the learning process through the application of discovery learning models, from the two cycles that have been implemented there are cognitive improvements as shown in Figure 4 


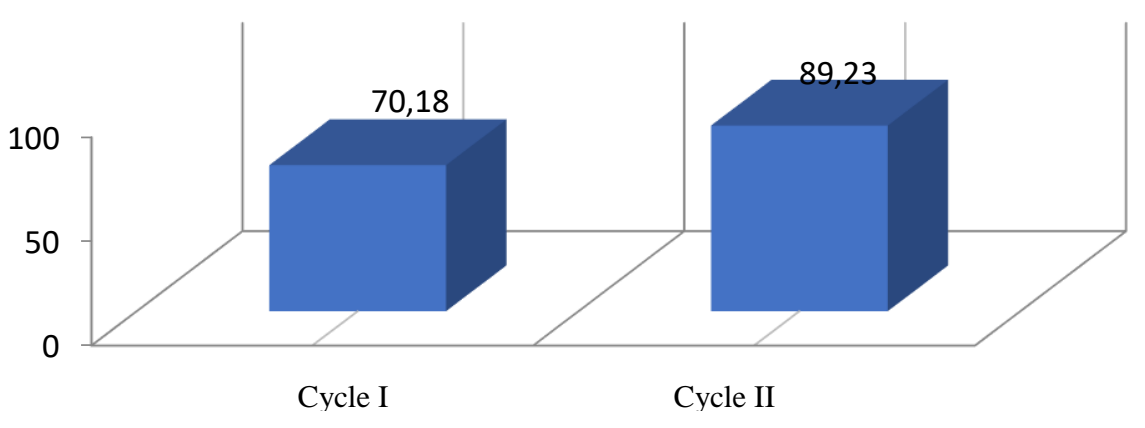

Figure 4. Cognitive Averages of the Cycle

The average cognitive value was seen to have increased from the average cognitive value in the first cycle of 70.18 in the sufficient category and experienced an increase in the second cycle with a value of 89.23 in the very high category. Improving cognitive learning outcomes is one proof that students have the ability to construct new knowledge as an effort to improve mastery of subject matter.

\section{Mastery learning students}

Data mastery learning students in the learning process through the application of discovery learning models, of the two cycles that have been implemented there is an increase in mastery learning as shown in Figure 5:

\section{Mastery learning students}

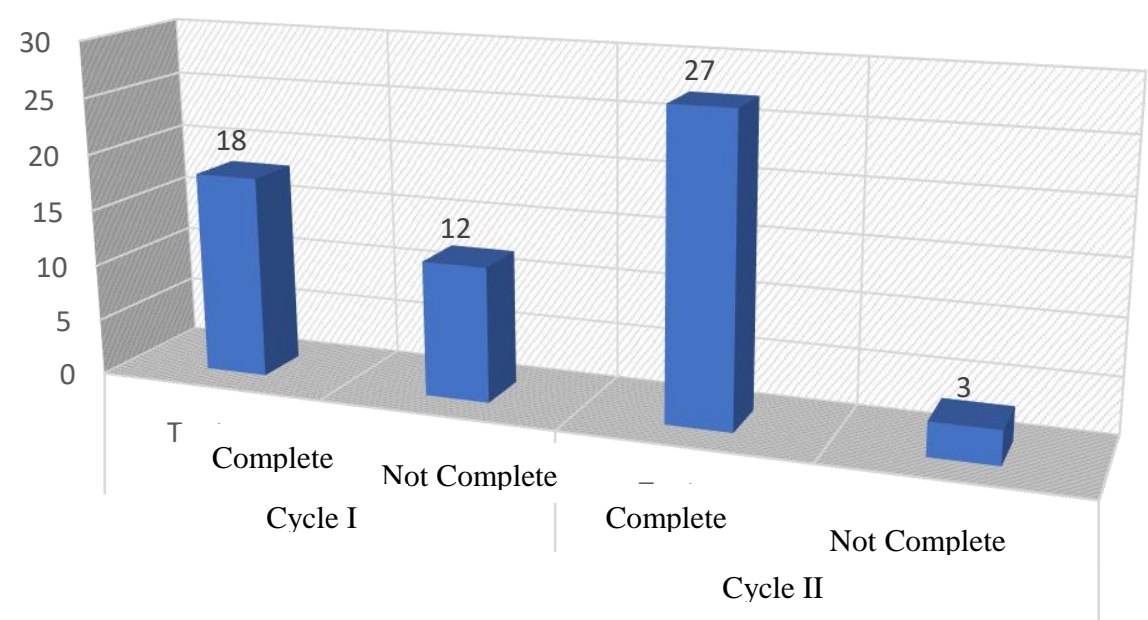

Figure 5. Mastery learning students every cycle

Acquiring the value of students' mastery learning through the application of discovery learning models, in the first cycle which was declared as complete as $18(60 \%)$ and incomplete namely 12 people (40\%). While the second cycle completed 27 people $(90 \%)$ and incomplete 3 people (10\%). This improvement illustrates that students have an effort in mastering subject matter, where learning is a process of adjusting and changing behavior.

\section{Discussion}

The findings show that the discovery learning model has a positive impact on improving students 'scientific and cognitive attitudes on learning geography which is characterized by an increase in students' mastery learning in each cycle. Teaching and learning activities of a teacher must have a strategy so that students can learn effectively and efficiently 
(Djamarah \& Zain, 2010). One step to having a method is to have to choose a material that is suitable and adapted to the student's character. Discovery learning emphasizes direct experience in the field, without having to always depend on learning theories contained in textbooks (Mulyasa, 2014). The innovative teaching methods helped students to appear creative, be more confident, and improve their critical thinking (Shaheen et al., 2015). The discovery learning model, students learn to think analytically and try to solve their own problems (YAUMI, 2017). Students are able to build relationships between theory and practice by using cognitive skills and cognitive meta (Akkuzu \& Uyulgan, 2017). Learning systems with guided discovery learning models oriented towards character education can improve student learning outcomes (Supliyadi et al., 2017). The implementation of discovery learning models can improve activities, critical thinking skills, and student physics learning outcomes (Gustika et al., 2018). The discovery learning process can improve the basic skills of the scientific process of high school students in the high category in the aspect of observing skills (Rizal, 2019).

\section{CONCLUSION AND SUGGESTION}

Discovery learning has a positive impact on improving students 'scientific and cognitive attitudes which are marked by an increase in students' learning completeness in each cycle. The scientific attitude of students in Cycle I shows an average value of 3.9 in either category. Cycle II The scientific attitude of students shows an average value of 4.4 in either category. While the average cognitive value was seen to increase in cycle I 70.18 in the sufficient category and experienced an increase in cycle II with a value of 89.23 in the very high category. This improvement illustrates that students have an effort in mastering subject matter, where learning is a process of adjusting and changing behavior.

To carry out active, effective and enjoyable learning requires preparation of the teacher in determining or choosing the subject matter that can really be applied using discovery learning models in order to obtain optimal results in the learning process.

\section{REFERENCE}

Akkuzu, N., \& Uyulgan, M. A. (2017). Step by step learning using the I diagram in the systematic qualitative analyses of cations within a guided inquiry learning approach. Chemistry Education Research and Practice, 18(4), 641-658.

Arikunto, S. (2010). Prosedur Penelitian Sebuah Pendekatan Praktek. Jakarta: Rineka Cipta.

Castronova, J. A. (2002). Discovery learning for the 21st century: What is it and how does it compare to traditional learning in effectiveness in the 21st century. Action Research Exchange, 1(1), 1-12.

Darling-Hammond, L. (2017). Teacher education around the world: What can we learn from international practice? European Journal of Teacher Education, 40(3), 291-309.

Daryato, H. M. (2011). Penelitian Tindakan Kelas dan Penelitian Tindakan Sekolah Beserta Contoh-contohnya. Yogyakarta: Gaya Media.

Djamarah, S. B., \& Zain, A. (2010). Strategi Belajar Mengajar Jakarta: Rineka Cipta.

Gustika, R., Sakti, I., \& Putri, D. H. (2018). Implementasi model pembelajaran penemuan (discovery learning model) untuk meningkatkan keterampilan berpikir kritis dan hasil belajar fisika di SMAN 3 Bengkulu Tengah. Jurnal Kumparan Fisika, 1(1 April), 1-6.

Hunter, A., \& Elliott-Kingston, C. (2014). Teaching and assessment strategies for active student learning in university horticultural education. In XXIX International Horticultural Congress on Horticulture: Sustaining Lives, Livelihoods and Landscapes (IHC2014): Plenary 1126.

Indarti, T. (2008). Penelitian tindakan kelas (ptk) dan penulisan ilmiah. Surabaya: FBS Unesa.

Kauchak, D., \& Eggen, P. (1992). Educational psychology: Classroom connections. Macmilian, New York, NY.

Kemmis, S., McTaggart, R., \& Nixon, R. (2013). The action research planner: Doing critical participatory action research. Springer Science \& Business Media.

Mulyasa, E. (2014). Guru dalam implementasi kurikulum 2013. Bandung: PT Remaja Rosdakarya Offset. 
Prakasiwi, R., \& Ismanto, B. (2018). Efforts to Improve Scientific Thinking Skills Through Application Discovery Model-Based Learning Environment Around. In Journal of Educational Science and Technology (EST) (Vol. 1, Issue 1).

Putriani, D., \& Rahayu, C. (2018). The Effect of Discovery Learning Model Using Sunflowers in Circles on Mathematics Learning Outcomes. In International Journal of Trends in Mathematics Education Research (Vol. 1, Issue 1).

Rizal, R. (2019). Implementasi Discovery Learning Untuk Meningkatkan Keterampilan Dasar Proses Sains Siswa SMA. In Journal of Teaching and Learning Physics (Vol. 4, Issue 1).

Sanjaya, W. (2010). Penelitian Tindakan Kelas, Prenada Media. Jakarta.

Shaheen, N., Alam, T., Mushtaq, M., \& Bukhari, M. A. (2015). Effects of inquiry based learning on the performance of students' at elementary level in Rawalpindi City: An experimental study. In Academic Research International (Vol. 6, Issue 2). SAVAP International (Society for the Advancement of Education through ....

Suendartia, M. (2017). The Effect of Learning Discovery Model on the Learning Outcomes of Natural Science of Junior High School Students Indonesia. In International Journal of Environmental \& Science Education (Vol. 12, Issue 10).
Sulfemi, W. B. (2016). Hubungan Persepsi Peserta Didik Tentang Kompetensi Guru Mata Pelajaran Sejarah Dengan Hasil Belajar Peserta Didik Mata Pelajaran Sejarah Di Kelas X SMA Negeri 1 Pamijahan Kabupaten Bogor. In Jurnal Fascho (Vol. 5, Issue 2).

Supliyadi, S., Baedhoni, M. I., \& Wiyanto, W. (2017). Penerapan model guided discovery learning berorientasi pendidikan karakter untuk meningkatkan hasil belajar siswa kelas xi SMA Negeri 1 Semarang tahun pelajaran 2017/2018. In Jurnal Profesi Keguruan (Vol. 3, Issue 2).

Wahjudi, E. (2015). Penerapan Discovery Learning Dalam Pembelajaran IPA Sebagai Upaya Untuk Meningkatkan Hasil Belajar Siswa Kelas IX-I Di SMP Negeri 1 Kalianget. In Jurnal Lensa (Vol. 5, Issue 1).

Widiadnyana, I. W., Sadia, I. W., \& Suastra, I. W. (2014). Pengaruh model discovery learning terhadap pemahaman konsep IPA dan sikap ilmiah siswa SMP. Jurnal Pendidikan Dan Pembelajaran IPA Indonesia, 4(2).

YAUMI, Y. (2017). Penerapan Perangkat Model Discovery Learning pada Materi Pemanasan Global untuk Melatihkan Kemampuan Literasi Sains Siswa SMP Kelas VII. Pensa: Jurnal Pendidikan Sains, $5(1)$. 